\title{
Relationship between chemical composition and magnetic susceptibility in sediment cores from Central Indian Ocean Basin
}

\author{
J N Pattan*, G Parthiban, V K Banakar, A Tomer and M Kulkarni \\ National Institute of Oceanography, Dona Paula, Goa 403 004, India. \\ *e-mail: pattan@nio.org
}

\begin{abstract}
Three sediment cores in a north-south transect $\left(3^{\circ} \mathrm{N}\right.$ to $\left.13^{\circ} \mathrm{S}\right)$ from different sediment types of the Central Indian Ocean Basin (CIOB) are studied to understand the possible relationship between magnetic susceptibility $(\chi)$ and $\mathrm{Al}, \mathrm{Fe}, \mathrm{Ti}$ and $\mathrm{Mn}$ concentrations. The calcareous ooze core exhibit lowest $\chi\left(12.32 \times 10^{-7} \mathrm{~m}^{3} \mathrm{~kg}^{-1}\right), \mathrm{Al}(2.84 \%), \mathrm{Fe}(1.63 \%)$ and $\mathrm{Ti}(0.14 \%)$, terrigenous clay core with moderate $\chi\left(29.93 \times 10^{-7} \mathrm{~m}^{3} \mathrm{~kg}^{-1}\right)$ but highest $\mathrm{Al}(6.84 \%), \mathrm{Fe}(5.20 \%)$ and $\mathrm{Ti}(0.44 \%)$, and siliceous ooze core with highest $\chi\left(38.06 \times 10^{-7} \mathrm{~m}^{3} \mathrm{~kg}^{-1}\right)$ but moderate $\mathrm{Al}(4.49 \%), \mathrm{Fe}(2.80 \%)$ and $\mathrm{Ti}(0.19 \%)$ contents. The distribution of $\chi$ and detrital proxy elements ( $\mathrm{Al}, \mathrm{Fe}$, and $\mathrm{Ti}$ ) are identical in both calcareous and siliceous ooze. Interestingly, in terrigenous core, the behaviour of $\chi$ is identical to only Ti content but not with $\mathrm{Al}$ and Fe suggesting possibility of $\mathrm{Al}$ and $\mathrm{Fe}$ having a non-detrital source.

The occurrence of phillipsite in terrigenous clay is evident by the Al-K scatter plot where trend line intersects $\mathrm{K}$ axis at more than $50 \%$ of total $\mathrm{K}$ suggesting excess $\mathrm{K}$ in the form of phillipsite. Therefore, the presence of phillipsite might be responsible for negative correlation between $\chi$ and $\mathrm{Al}(r=-0.52)$. In siliceous ooze the strong positive correlations among $\chi, \mathrm{Al}_{\text {exc }}$ and $\mathrm{Fe}_{\text {exc }}$ suggest the presence of authigenic Fe-rich smectite. High Mn content (0.5\%) probably in the form of manganese micronodules is also contributing to $\chi$ in both calcareous and siliceous ooze but not in the terrigenous core where mean Mn content $(0.1 \%)$ is similar to crustal abundance. Thus, $\chi$ systematically records the terrigenous variation in both the biogenic sediments but in terrigenous clay it indirectly suggests the presence of authigenic minerals.
\end{abstract}

\section{Introduction}

Terrigenous material in marine sediments is generally supplied by fluvial and aeolin sources. The variation in the amount and nature of terrigenous material in sediment, through time, can be traced by the simple measurement of $\chi$ (Verosub and Roberts 1995). The $\chi$ of sediment is largely due to the presence of magnetic minerals (Currie and Bornhold 1983). The spatial and temporal distribution of $\chi$ in sediments is not only due to variable abundance of iron-bearing ferriand anti-ferromagnetic minerals, but also due to the presence of diamagnetic and paramagnetic minerals such as quartz, feldspar, carbonates and clays (Bareille et al 1994). Therefore, temporal records of sedimentary $\chi$ might indicate changes in relative variations of biogenic, authigenic, and terrigenous components. The $\chi$ has been widely used in conjunction with several other palaeoclimate proxies such as calcium carbonate and oxygen isotopes in deep sea sediments as a useful paleoclimate indicator (Kent 1982; Robinson 1986; Mead et al 1986; Doh et al 1988; Sager and Hall 1990; Bloemendal et al 1988, 1992), changing sedimentary environment (Curry et al 1995) and

Keywords. Central Indian Ocean Basin; sediment cores; magnetic susceptibility; elemental concentration; terrigenous; phillipsite; Fe-rich smectite; micronodules. 
Table 1. Details of sediment cores from the Central Indian Ocean Basin.

\begin{tabular}{lccccc}
\hline Core no. & Latitude & Longitude & $\begin{array}{c}\text { Water depth } \\
(\mathrm{m})\end{array}$ & $\begin{array}{c}\text { Core length } \\
(\mathrm{cm})\end{array}$ & Sediment type \\
\hline AAS-01/SPC-18 & $02^{\circ} 59^{\prime} \mathrm{N}$ & $77^{\circ} 10^{\prime} \mathrm{E}$ & 4068 & 31.5 & Calcareous ooze \\
AAS-40/GC-02 & $02^{\circ} 59^{\prime} \mathrm{S}$ & $77^{\circ} 10^{\prime} \mathrm{E}$ & 5000 & 479 & Terrigenous sed \\
AAS-27/GC-01 & $13^{\circ} 02^{\prime} \mathrm{S}$ & $77^{\circ} 09^{\prime} \mathrm{E}$ & 5400 & 551 & Siliceous ooze \\
\hline
\end{tabular}

pollution studies (Petrovsky et al 1998; Maiti et al 2005).

Shankar et al (1994) studied a large number of deep Arabian Sea surface sediments and suggested that $\chi$ can be used to estimate the iron content of marine sediments. In CIOB long sediment cores were not studied for $\chi$ and no effort had been made to correlate $\chi$ with detrital and authigenic fractions of individual elements. The $\chi$ variability in sediments of the northern Indian Ocean was investigated to understand climate-driven changes during the Quaternary (Bloemendal and de Menocal 1989; Colin et al 1998; Sangode et al 2001; Anil Kumar et al 2005) and weathering history of Himalayas (Chauhan et al 2004). As the $\chi$ could be a potential indicator of terrigenous material supply to deep ocean floor and, the Himalayan detritus reaching far south in the southern hemisphere of Indian Ocean (Banakar et al 2003), it may be possible to obtain records of past-changes in continental supply by monitoring past-variability of $\chi$. Therefore in this study, we investigate the causes of $\chi$ variations in different types of sediments, such as calcareous, siliceous ooze and terrigenous clay in the CIOB. Further, we evaluate dominant components responsible for any such variability in the sediment.

\section{Materials and methods}

Three sediment cores utilized for the present study were collected onboard R. V. A. A. Siderenko during cruise nos. 1, 27 and 40. Each of these three sediment cores (table 1) represents different sediment type, viz., calcareous ooze (AAS-01/SPC-18), terrigenous clay (AAS-40/GC-02) and siliceous ooze (AAS-27/GC-01) (figure 1). The calcareous core was $31.5 \mathrm{~cm}$ long and sub-sampled at $3 \mathrm{~cm}$ intervals, whereas siliceous and terrigenous cores were $5.5 \mathrm{~m}$ and $4.8 \mathrm{~m}$ long respectively and subsampled at $2 \mathrm{~cm}$ intervals. Here onwards AAS01/SPC-01 (calcareous core) is referred to as CC, AAS-40/GC-02 (terrigenous core) as TC and AAS-27/GC-01 (siliceous core) as SC for convenience.

All sub-samples were oven dried at $40^{\circ} \mathrm{C}$ and powdered in agate mortar. The dried powders were

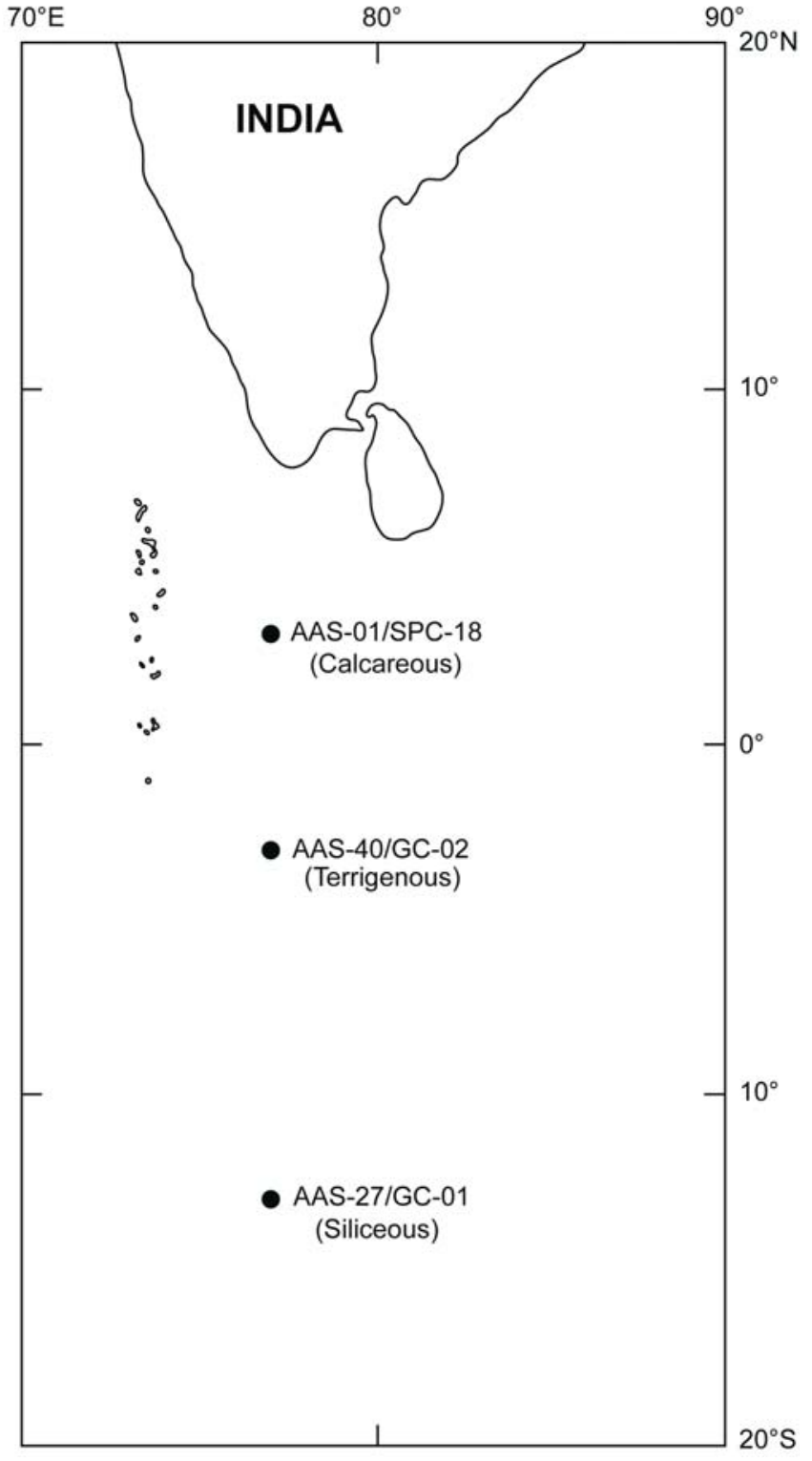

Figure 1. Location map showing three sediment cores from CIOB.

used to measure the $\chi$ and analysed for $\mathrm{Al}, \mathrm{Fe}, \mathrm{Ti}$ and Mn concentrations. For $\chi$ measurements, accurately weighed aliquots were packed in $8 \mathrm{~cm}^{3}$ pots and immobilized by covering with plastic films. Volume magnetic susceptibility $(\kappa)$ was measured on a Barrington Instruments ${ }^{\circledR}$ MS-2 Susceptibility Meter with MS2B dual frequency sensor $(460 \mathrm{~Hz}$ 
and $4600 \mathrm{~Hz})$. Low frequency, $\left(\kappa_{\mathrm{lf}}, 0.46 \mathrm{kHz}\right)$ and high frequency $\left(\kappa_{\mathrm{hf}}, 4.6 \mathrm{kHz}\right)$ were measured twice for each sample on 0.1 range and the average of the two measurements was considered. Mass specific values were calculated and expressed as $\mathrm{m}^{3} \mathrm{~kg}^{-1}$, using $\chi=\kappa / \rho$, where $\rho$ is the dry bulk density and $\kappa$ is volume-specific. Measurements of frequencydependent susceptibility $\left(\chi_{\mathrm{fd}} \%\right)$ is calculated as $\chi_{\mathrm{fd}} \%=\left(\chi_{\mathrm{lf}}-\chi_{\mathrm{hf}}\right) / \chi_{\mathrm{lf}} \times 100$ (Yamazaki and Ioka 1997). The $\chi_{\mathrm{fd}} \%$ is useful for detecting the presence of super paramagnetic grains (Bloemendal et al 1985).

$\mathrm{Al}, \mathrm{Fe}, \mathrm{Ti}$ and $\mathrm{Mn}$ concentrations were measured in the aliquots of sub-sections of all three sediment cores $(n=522)$ on a Perkin-Elmer Optima 2000 ICP-OES using solutions prepared in a mixture of $\mathrm{HF}, \mathrm{HClO}_{4}$ and $\mathrm{HNO}_{3}$ in an open vessel digestion protocol (see Parthiban 2005). International reference standard material MAG-1 was used to check the accuracy and duplicate analysis for precision. The results were accurate and precise to within $\pm 4 \%$ for the elements analysed. Structurally unsupported element concentration was estimated as excess element $\left(E_{\text {exc }}\right)$ content following Murray and Leinen (1996) empirical relationship:

$$
E_{\text {exc }}=E_{\text {tot }} X-\left[\operatorname{Ti}_{\text {Sample }} X\left(E / \operatorname{Ti}_{\text {Shale }}\right)\right]
$$

where $E$ is element of interest.

The $E_{\text {exc }}$ concentration was then subtracted from the total content of respective element to obtain detrital fraction. The other alternative to get the detrital and structurally unsupported fraction in the sediment is by leaching/partition geochemistry, which itself is a separate aspect. However, in calculating the $E_{\text {exc }}$ we assumed a uniform element/Ti of shale throughout the core depth. The estimation of $E_{\text {exc }}$ using empirical formula is reasonably well accepted (Murray and Leinen 1993; Banakar et al 1998; Pattan and Shane 1999).

\section{Results and discussion}

\subsection{Magnetic susceptibility}

The $\chi$ is directly related to magnetic material in the sediment and is the total contribution from all Fe-bearing minerals (Thomson and Oldfield 1986; Verosub and Roberts 1995) and is affected by dia- and para-magnetic minerals resulting in dilution. The $\chi, \mathrm{Al}, \mathrm{Fe}$, and $\mathrm{Ti}$ data of all three sediment cores are plotted against the core depth (figures 2-4). Maximum, minimum and mean values of low-frequency $\left(\chi_{\mathrm{lf}}\right)$, high-frequency $\left(\chi_{\mathrm{hf}}\right)$ and frequency dependence $\left(\chi_{\mathrm{fd}} \%\right)$ are presented in table 2. In general, the mean $\chi_{\text {lf }}$ is low

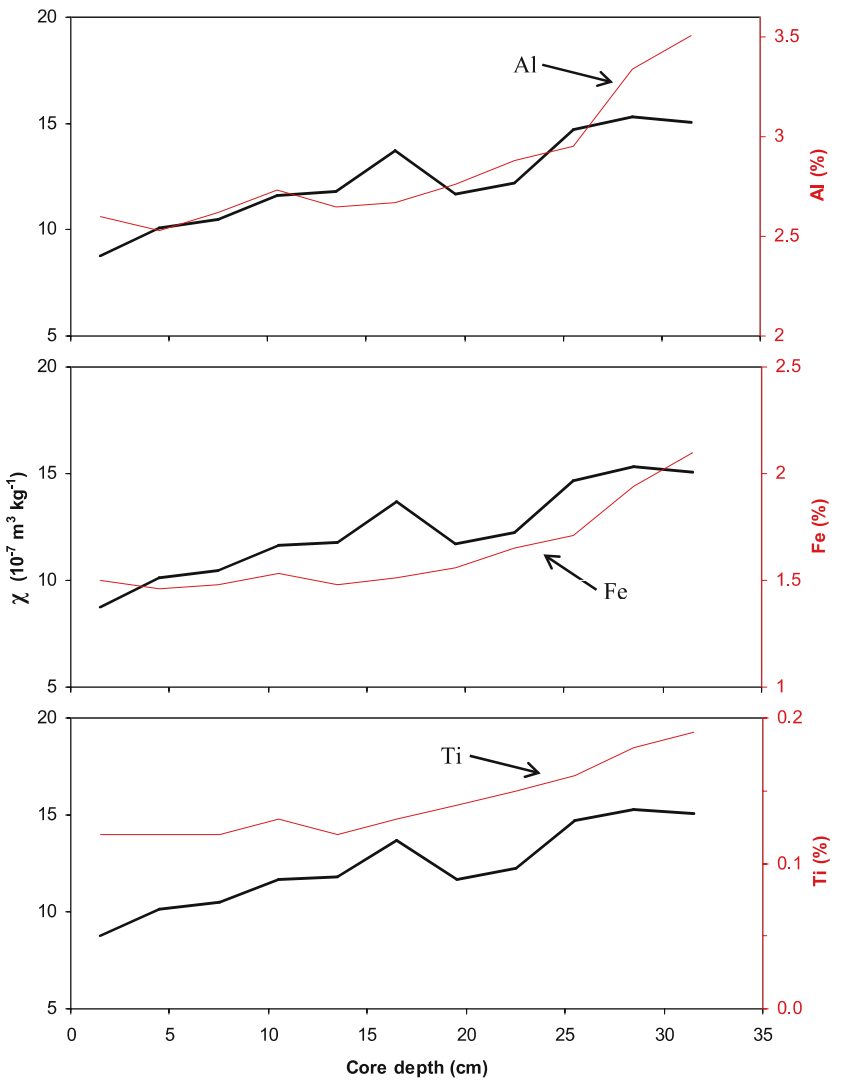

Figure 2. Variation of magnetic susceptibility along with $\mathrm{Al}(\%), \mathrm{Fe}(\%)$ and $\mathrm{Ti}(\%)$ content in a calcareous ooze core (AAS-01/SPC-18) from CIOB.

in $\mathrm{CC}\left(12.32 \times 10^{-7} \mathrm{~m}^{3} \mathrm{~kg}^{-1}\right)$, moderate in $\mathrm{TC}$ $\left(29.93 \times 10^{-7} \mathrm{~m}^{3} \mathrm{~kg}^{-1}\right)$, and high in $\mathrm{SC}(38.06 \times$ $10^{-7} \mathrm{~m}^{3} \mathrm{~kg}^{-1}$ ) (table 2). These mean values of $\chi_{\mathrm{lf}}$ suggest that the magnetic minerals are more abundant in SC compared to the other two sediment types. The $\chi$ in CC has nearly $2-3$ times lower than $\mathrm{SC}$ and $\mathrm{TC}$ and shows increasing trend with the core depth (figure 2). The TC is closer to continent compared to $\mathrm{SC}$ but the $\chi$ values are lower ranging from 9.78 to $83.47 \times 10^{-7} \mathrm{~m}^{3} \mathrm{~kg}^{-1}$ with an average of $29.93 \times 10^{-7} \mathrm{~m}^{3} \mathrm{~kg}^{-1}$ (figure 3 ). The low values of $\chi$ are observed in the top $50 \mathrm{~cm}, 135$ to $155 \mathrm{~cm}, 225$ to $250 \mathrm{~cm}$, and 275 to $460 \mathrm{~cm}$ depthsections in the core, with more or less uniformly low values between $275 \mathrm{~cm}$ and $460 \mathrm{~cm}$ depth (figure 3 ). These variations are obviously related to monsoonal intensity on the Indian subcontinent. The SC shows considerable variation in $\chi$ ranging from 19.14 to $50.40 \times 10^{-7} \mathrm{~m}^{3} \mathrm{~kg}^{-1}$ with an average of $38.06 \times 10^{-7} \mathrm{~m}^{3} \mathrm{~kg}^{-1}$ (figure 4). The $\chi$ is higher in the top $200 \mathrm{~cm}$ and below $400 \mathrm{~cm}$ and reaches a minimum at $\sim 300 \mathrm{~cm}$ depth in core. The lowest $\chi$ at $\sim 300 \mathrm{~cm}$ depth in core (figure 4 ) may be suggestive of significantly reduced sediment input from the Ganges-Brahmaputra river system probably due to arid conditions. The $\mathrm{Nd}-\mathrm{Sr}$ isotopic studies 


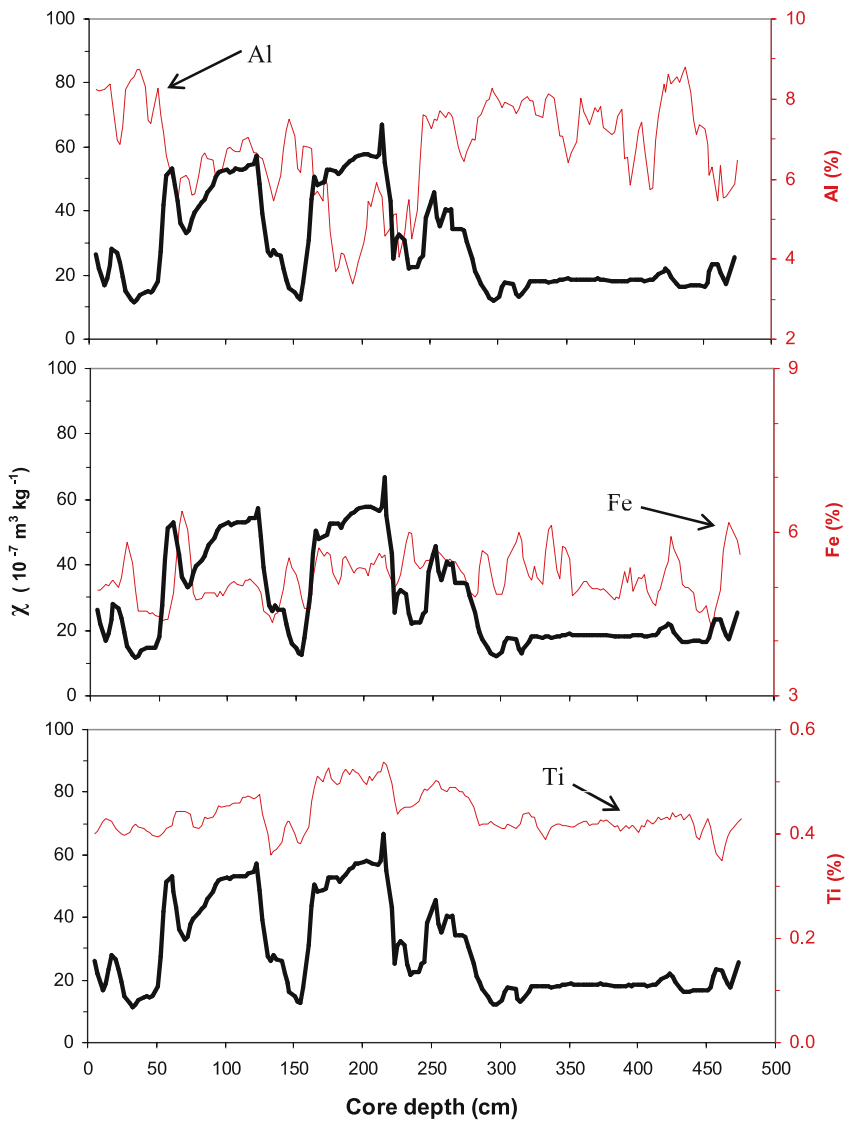

Figure 3. Variation of magnetic susceptibility along with

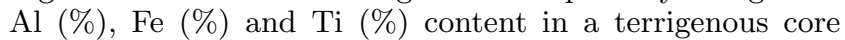
(AAS-40/GC-02) from CIOB.

of detrital fractions of the CIOB sediment and $\mathrm{Fe}-\mathrm{Mn}$ crusts have clearly indicated that most of the terrigenous material has originated from High Himalayan Crystalline Series (Fagel et al 1994; Banakar et al 2003). There are few significant fluctuations in $\chi$ throughout the depth indicative of weak and strong monsoonal rainfall, which brings the detrital fraction into CIOB (figures 3 and 4). The non-availability of a time-scale for the studied sediment cores renders interpretation in terms of past climate changes rather non-feasible.

\subsection{Relationship between elemental} concentration and magnetic susceptibility

Average concentrations of $\mathrm{Al}, \mathrm{Fe}, \mathrm{Ti}, \mathrm{Mn}$, and $\chi$ values for all three sediment cores along

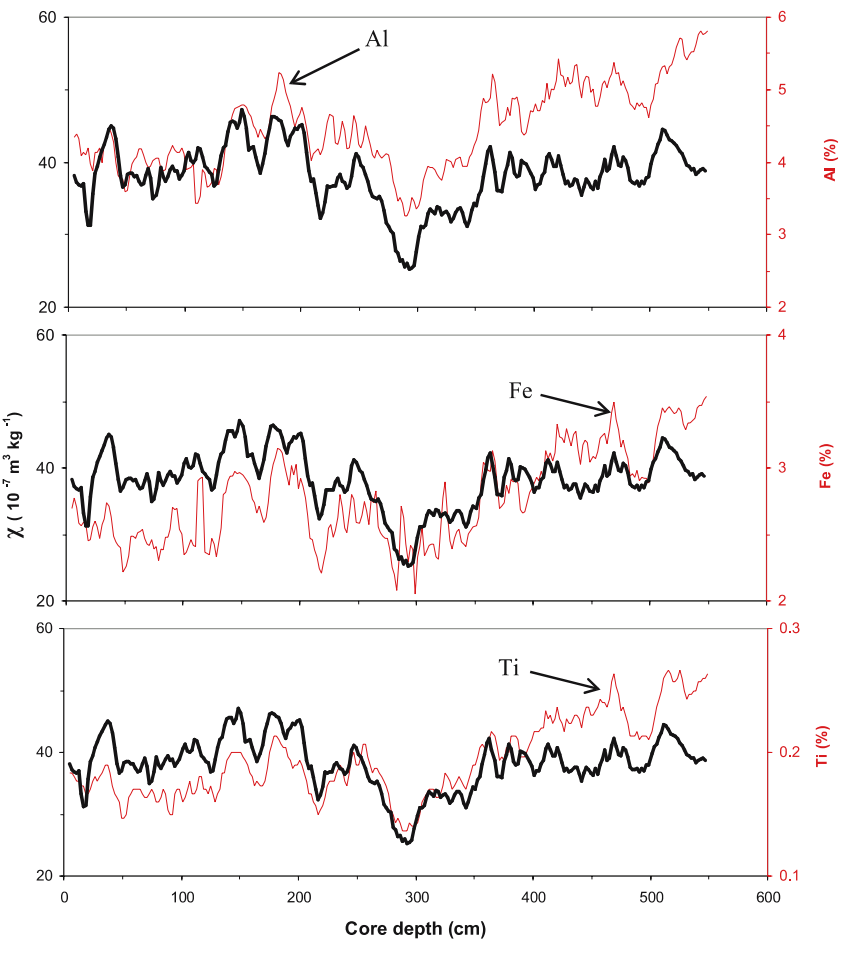

Figure 4. Variation of magnetic susceptibility along with $\mathrm{Al}(\%), \mathrm{Fe}(\%)$ and $\mathrm{Ti}(\%)$ content in a siliceous core (AAS-27/GC-01) from CIOB.

with inter-elemental correlations are presented in table 3. As expected: (a) in CC, the mean concentrations of $\mathrm{Al}(2.84 \%), \mathrm{Fe}(1.63 \%), \mathrm{Ti}$ $(0.14 \%)$ and $\chi\left(12.32 \times 10^{-7} \mathrm{~m}^{3} \mathrm{~kg}^{-1}\right)$ are low due to dilution by calcium carbonate; (b) the TC record highest content of $\mathrm{Al}(6.84 \%)$, Fe $(5.2 \%)$ and $\mathrm{Ti}(0.44 \%)$ but associated with moderate $\chi$ $\left(29.93 \times 10^{-7} \mathrm{~m}^{3} \mathrm{~kg}^{-1}\right)$ and (c) SC has moderate content of $\mathrm{Al}(4.49 \%)$, $\mathrm{Fe}(2.80 \%)$, Ti $(0.19 \%)$ and high $\chi\left(38.06 \times 10^{-7} \mathrm{~m}^{3} \mathrm{~kg}^{-1}\right)$. These chemical data suggest that TC receives nearly 2 and 3 -fold increased detrital sediment input compared to $\mathrm{CC}$ and $\mathrm{SC}$ respectively. But the $\chi$ is higher in $\mathrm{SC}$ $\left(38.06 \times 10^{-7} \mathrm{~m}^{3} \mathrm{~kg}^{-1}\right)$ compared to TC $(29.93 \times$ $10^{-7} \mathrm{~m}^{3} \mathrm{~kg}^{-1}$ ). In CC and SC, a mutually strong positive correlation $(r>0.87$ : table 3$)$ between $\mathrm{Al}$, $\mathrm{Fe}$, and $\mathrm{Ti}$ suggests their common source mainly from terrigenous fraction. Contrastingly, in TC, the $\mathrm{Al}$ is negatively correlated with $\mathrm{Ti}(r=-0.24)$ suggesting that $\mathrm{Al}$ is not derived from detrital source, on the other hand, $\mathrm{Al}$ and $\mathrm{Fe}$ exhibit no mutual

Table 2. Low frequency, high frequency and frequency dependent parameter for all three sediment cores from CIOB.

\begin{tabular}{|c|c|c|c|c|c|c|c|c|c|}
\hline \multirow[b]{2}{*}{ Core no. } & \multicolumn{3}{|c|}{$\chi_{\mathrm{lf}}\left(10^{-7} \mathrm{~m}^{3} \mathrm{~kg}^{-1}\right)$} & \multicolumn{3}{|c|}{$\chi_{\mathrm{hf}}\left(10^{-7} \mathrm{~m}^{3} \mathrm{~kg}^{-1}\right)$} & \multicolumn{3}{|c|}{$\chi_{\mathrm{fd}} \%$} \\
\hline & Max. & Min. & Avg. & Max. & Min. & Avg. & Max. & Min. & Avg. \\
\hline AAS-01/SPC-18 & 15.32 & 8.75 & 12.32 & 14.82 & 8.21 & 11.29 & 18.75 & 00 & 8.53 \\
\hline AAS-40/GC-02 & 83.47 & 9.78 & 29.93 & 82.67 & 8.50 & 28.58 & 13.20 & 00 & 3.30 \\
\hline AAS-27/GC-01 & 50.40 & 19.14 & 38.06 & 47.81 & 20.73 & 34.07 & 23.30 & 4.60 & 10.75 \\
\hline
\end{tabular}


Table 3. Some important elemental concentration (average), magnetic susceptibility values and correlation between $\chi$ and geochemical elements (bulk, excess and detrital fractions) in three sediment cores from CIOB.

\begin{tabular}{|c|c|c|c|}
\hline Core no. & AAS-01/SPC-18 & AAS-40/GC-01 & AAS-27/GC-02 \\
\hline Sediment type & Calcareous & Terrigenous & Siliceous \\
\hline No. of sub-samples & $n=11$ & $n=236$ & $n=275$ \\
\hline$\chi\left(10^{-7} \mathrm{~m}^{3} \mathrm{~kg}^{-1}\right)$ & 12.32 & 29.93 & 38.06 \\
\hline$\chi \mathrm{fd}(\%)$ & 8.53 & 3.30 & 10.75 \\
\hline $\mathrm{Al}$ (mean) (\%) & 2.84 & 6.84 & 4.49 \\
\hline $\mathrm{Fe}(\mathrm{mean})(\%)$ & 1.63 & 5.20 & 2.80 \\
\hline Ti (mean) (\%) & 0.14 & 0.44 & 0.19 \\
\hline Mn (mean) $(\%)$ & 0.46 & 0.10 & 0.53 \\
\hline $\mathrm{Al}_{\text {exc }}(\%)$ & 16.0 & 12.0 & 28.0 \\
\hline $\mathrm{Fe}_{\mathrm{exc}}(\%)$ & 31.0 & 36.0 & 46.0 \\
\hline $\operatorname{Mn}_{\operatorname{exc}}(\%)$ & 84.0 & 26.0 & 94.0 \\
\hline Al-Fe (bulk) correlation & $r=+0.99$ & $r=+0.06$ & $r=+0.87$ \\
\hline Al-Ti & $r=+0.98$ & $r=-0.24$ & $r=+0.92$ \\
\hline $\mathrm{Fe}-\mathrm{Ti}$ & $r=+0.98$ & $r=+0.35$ & $r=+0.88$ \\
\hline Al-Mn & $r=+0.98$ & $r=+0.17$ & $r=+0.39$ \\
\hline$\chi-\mathrm{Al}_{\text {exc }}$ correlation & $r=-0.77$ & $r=-0.17$ & $r=+0.25$ \\
\hline$\chi$-Al detrital & $r=+0.85$ & $r=-0.37$ & $r=+0.43$ \\
\hline$\chi$-Al bulk & $r=+0.82$ & $r=-0.52$ & $r=+0.47$ \\
\hline$\chi-\mathrm{Fe}_{\text {exc }}$ correlation & $r=+0.25$ & $r=-0.28$ & $r=+0.33$ \\
\hline$\chi$-Fe detrital & $r=+0.86$ & $r=+0.69$ & $r=+0.43$ \\
\hline$\chi$-Fe bulk & $r=+0.78$ & $r=+0.16$ & $r=+0.45$ \\
\hline$\chi$-Ti correlation & $r=+0.85$ & $r=+0.69$ & $r=+0.43$ \\
\hline$\chi-\mathrm{Mn}_{\mathrm{exc}}$ & $r=+0.83$ & $r=-0.12$ & $r=+0.39$ \\
\hline
\end{tabular}

association $(r=0.06)$ suggesting their independent sources (table 3; also see Parthiban 2005). This type of correlation is rarely observed in the marine sediments.

The positive correlation between $\mathrm{Fe}$ and $\mathrm{Ti}$ in both CC $(r=0.98)$ and SC $(r=0.88)$ sediments suggests the possible presence of titanomagnetite minerals. In spite of the dominance of biogenic components in both these sediment types, $\chi$ follows $\mathrm{Al}, \mathrm{Fe}$, and $\mathrm{Ti}$ trend within the sediment cores (figures 2 and 4). In $\mathrm{TC}, \mathrm{Fe}$ and $\mathrm{Ti}$ are not strongly correlated $(r=0.35)$ as compared to SC and $\mathrm{CC}(r=0.9)$, suggesting that a major portion of $\mathrm{Fe}$ may have been associated with authigenic minerals.

In general, $\chi$ positively correlates with $\mathrm{Ti}$ content in all the three cores, whereas it is positively correlated with $\mathrm{Al}$ and $\mathrm{Fe}$ content in both $\mathrm{CC}$ and $\mathrm{SC}$, but is negatively correlated with $\mathrm{Al}$ and no relation with $\mathrm{Fe}$ in TC (table 3 ). To further refine the observed relationships between $\chi$ and elemental concentrations, we have portioned the bulk chemical data into detrital and nondetrital $\left(\mathrm{El}_{\text {exc }}\right)$ and is presented in table 3 . The $\mathrm{Al}_{\text {exc }}$ and $\mathrm{Fe}_{\text {exc }}$ are lower in $\mathrm{CC}$ and $\mathrm{TC}$ compared to SC (table 3 ). The $\chi$ exhibits a negative correlation with $\mathrm{Al}_{\text {exc }}(r=-0.77)$ in $\mathrm{CC}$ because biogenic carbonate is diamagnetic in nature and probably diluting $\chi$. The high calcium carbonate content (55\%, Parthiban 2005) in the CC is due to its location $(4068 \mathrm{~m})$ above the carbonate compensation depth (Banakar et al 1998). The negative correlation between carbonate and $\chi$ is similar to the earlier observations (Curry et al 1995; Frederichs et al 1999). In CC, $\mathrm{Al}_{\mathrm{exc}}$ and calcium carbonate show strong positive correlation $(r=0.86)$ (Parthiban 2005). This probably suggests that settling biogenic tests effectively scavenge dissolved $\mathrm{Al}$ from the water column (Murray and Leinen 1996; Banakar et al 1998).

In both $\mathrm{SC}$ and $\mathrm{TC}$, the $\chi$ and $\mathrm{Al}_{\text {exc }}$ exhibit a weak positive $(r=+0.25)$ and negative $(r=$ -0.17 ) correlations respectively. This suggests that $\mathrm{Al}_{\text {exc }}$ in both these cores has multiple associations. The $\mathrm{Al}_{\text {exc }}$ in marine sediment could also be due to the presence of authigenic Fe-rich smectite (Timothy and Calvert 1998; Pattan et al 2005) and volcanic ash of rhyolitic composition (Pattan and Shane 1999). The absence of volcanic ash and no correlation between biogenic opal and $\mathrm{Al}_{\mathrm{exc}}$ (Parthiban 2005), and presence of Fe-rich smectite in CIOB sediments (Pattan et al 2005) with 
a positive $\chi$ (Frederichs et al 1999), might be responsible for the observed positive correlation. The moderate positive correlation between $\mathrm{Fe}_{\text {exc }}$ and $\mathrm{Al}_{\text {exc }}(r=0.35)$ further supports the presence of Fe-rich smectite. These types of relationships are not evident in TC. The negative correlation between $\chi$ and $\mathrm{Fe}_{\text {exc }}$ in TC $(r=-0.28)$ suggests that Fe possibly has association with very fine biogenic magnetite precipitated by bacteria under suboxic/anoxic conditions (Kirschvink et al 1984; Stolz et al 1986; Ellwood et al 2000). In this core, suboxic conditions are evident by very low Mn content $(<0.1 \%)$ which is similar to crustal abundance. The high organic carbon $(0.48 \%$ to $2.31 \%$ ) content with very fine grain sediment texture (clay content $>95 \%$ ) (Parthiban 2005), might have provided favourable conditions for the formation of fine biogenic magnetite. Therefore, we suspect that biogenic magnetite of diamagnetic nature might be responsible for non-association of bulk $\mathrm{Al}$ and $\mathrm{Fe}(r=0.01)$, and negative correlation between $\chi$ and $\mathrm{Fe}_{\text {exc }}(r=-0.27)$ in TC. Further study needs to confirm the presence of biogenic magnetite.

The $\mathrm{Fe}_{\text {exc }}$ is low in CC (31\%) and TC (36\%) as compared to SC (46\%). The correlation between $\chi$ and $\mathrm{Fe}_{\text {exc }}$ in $\mathrm{SC}$ is positive $(r=0.33)$, whereas in TC it is negative $(r=-0.28)$ suggesting different phases of $\mathrm{Fe}_{\text {exc }}$ in these two cores. This is confirmed by our earlier observations that $\mathrm{Fe}_{\text {exc }}$ in $\mathrm{SC}$ and $\mathrm{TC}$ is associated with Fe-rich smectite and biogenic magnetite respectively. In $\mathrm{TC}, \mathrm{Al}$ and $\mathrm{K}$ show a strong positive correlation $(r=0.61)$ and the best-fit line intersects the $\mathrm{K}$ axis at $1.4 \%$ suggesting that nearly $50 \%$ of $\mathrm{K}$ is of non-detrital nature (Parthiban 2005). This non-detrital or $K_{\text {exc }}$ might be in the form of phillipsite, which is diamagnetic in nature and probably responsible for the negative correlation between $\mathrm{Al}$ and $\chi(r=-0.52)$. The manganese content in $\mathrm{CC}(0.46 \%)$ and SC $(0.53 \%)$ is enriched nearly five times compared to that in TC $(0.1 \%)$. Similarly as expected, $\mathrm{Mn}_{\mathrm{exc}}$ is also high ( $84 \%$ to $94 \%$ ) in both CC and SC compared to TC (26\%), suggesting that the former two sediment-types experience higher oxidizing conditions than the latter type. Assuming 0.1\% of Mn in TC as silicate structure bound component, the high Mn content in both CC and SC may be authigenic in nature, probably in the form of dispersed particalate $\mathrm{Mn}$-oxide or manganese micronodules. There is a positive correlation between $\chi$ and $\mathrm{Mn}_{\text {exc }}$ in both CC and SC (table 3). In TC, only top $20 \mathrm{~cm}$ of the core contains $\mathrm{Mn}_{\text {exc }}$ resulted by diagenetic remobilization and below $20 \mathrm{~cm}$ depth there is no $\mathrm{Mn}_{\mathrm{exc}}$. This might have resulted into a no correlation between $\chi$ and $\mathrm{Mn}_{\text {exc }}$ (table 3). Therefore, $\chi$ indirectly suggests the presence of authigenic phillipsite, Fe-rich smectite, manganese micronodules and biogenic magnetite in the CIOB sediments.

The frequency dependence of magnetic susceptibility $\left(\chi_{\mathrm{fd}}\right)$ is a diagnostic parameter to understand the magnetic grain variation (Yamazaki and Ioka 1997). The average $\chi_{\mathrm{fd}}$ of $\mathrm{CC}$ and $\mathrm{SC}$ is higher ( $8.53 \%$ and $10.75 \%$ respectively) compared to that of TC $(3.3 \%)$. This suggests that TC consists of mainly detrital material which is evident by the textural analysis where clay content is $>95 \%$.

\section{Conclusions}

We investigated the relationship between magnetic susceptibility and chemical composition (bulk, detrital and non-detrital fractions) of three different sediment types from the CIOB. The results of this study demonstrate the following:

- Low frequency magnetic susceptibility $(\chi)$ can be used as an indicator of terrigenous influence in both carbonate and siliceous sediment types, where it behaves identical to that of detrital representing elements such as $\mathrm{Al}, \mathrm{Fe}$ and $\mathrm{Ti}$. On the other hand, in terrigenous sediment, $\chi$ behaves similar to only Ti content, but not with $\mathrm{Al}$ and Fe suggesting that both $\mathrm{Al}$ and Fe are not derived by the detrital source.

- The correlation between $\chi$ and non-silicate element proportions in these studied sediment indirectly suggests the presence of authigenic minerals such as phillipsite, Fe-rich smectite and manganese micronodules. This further indicates active post-depositional diagenetic processes within the sediment.

\section{Acknowledgements}

We are thankful to the Director, National Institute of Oceanography, Goa for the permission to publish this paper. We are grateful to Dr. R Shankar for his constructive review and Dr. N Basavaiah for discussions. This is NIO contribution no. 4316.

\section{References}

Anil Kumar A, Purnachandra Rao V, Patil S K, Kessarkar P and Thamban M 2005 Rock magnetic records of the sediments of the eastern Arabian Sea: Evidence for Late Quaternary climatic changes; Mar. Geol. 220 59-82.

Banakar V K, Parthiban G, Pattan J N and Jauhari P 1998 Chemistry of surface sediment along a north-south transect across the equator in the Central Indian Basin: an assessment of biogenic and detrital influences on elemental burial on the seafloor; Chem. Geol. 147 217-232.

Banakar V K, Galy A, Sukumaran N P, Parthiban G and Volvaikar A Y 2003 Himalayan sedimentary pulses recorded by silicate detritus within a ferromanganese Crust from Central Indian Ocean; Earth Planet. Sci. Letts. 205 337-348. 
Bareille G, Grousset F E, Labracherie M, Labeyrie L D and Petit J R 1994 Origin of detrital fluxes in the southeast Indian Ocean during the last climatic cycles; Paleoceanography 9 799-819.

Bloemendal J and de Menocal P 1989 Evidence for a change in the periodicity of tropical climate cycles at $2.4 \mathrm{Myr}$ from whole core magnetic susceptibility measurement; Nature 342 897-900.

Bloemendal J, Barton C E and Radhakrishnamurthy C 1985 Correlation between Rayleigh loops and frequency dependent and quadrature susceptibility: Applications to magnetic granulometry of rocks; J. Geophys. Res. 90 8789-8792.

Bloemendal J, Lamb B and King J 1988 Paleoenvironmental implications of rock magnetic properties of late Quaternary sediment cores from the eastern Equatorial Atlantic; Paleoceanography 3 61-87.

Bloemendal J, King J W, Hall F R and Doh S J 1992 Rock magnetism of Late Neogene and Pleistocene deepsea sediments: Relationship to sediment source, diagenetic process and sediment lithology; J. Geophys. Res. 97 $4361-4375$.

Chauhan O S, Patil Shiva K, Suneethi J 2004 Fluvial influx and weathering history of the Himalayas since Last Glacial Maxima - isotopic, sedimentological and magnetic records from the Bay of Bengal; Curr. Sci. 87 509-515.

Colin C, Kissel C, Blamart D and Turpin L 1998 Magnetic properties of sediments in the Bay of Bengal and the Andaman Sea: impact of rapid North Atlantic Ocean climatic events on the strength of the Indian monsoon; Earth Planet. Sci. Letts. 160 623-635.

Currie R G and Bornhold B D 1983 The Magnetic susceptibility of Continental-shelf Sediments, West coast Vancouver Island, Canada; Mar. Geol. 51 115-127.

Curry W B, Shackleton N J and Richter et al 1995 Proc. ODP. Int. Repts., 154. College Station, Tx (Ocean Drilling Program).

Doh S J, King J W and Leinen M 1988 A rock magnetic study of giant piston Core LL44-GPC3 from the central North Pacific and its paleoceanographic implication; Paleoceanography 3 89-111.

Ellwood B B, Crick R E, Hassani A E, Benoist S L and Young R H 2000 Magnetic susceptibility event and cyclostratigraphy method applied to marine rocks: Detrital versus carbonate productivity; Geology 28 1135-1138.

Fagel N, Debrabant P and Andre L 1994 Clay supplies in the Central Indian Basin since the Late Miocene: climatic or tectonic control?; Mar. Geol. 122 151-172.

Frederichs T, Bleil U, Daumler K, Dobeneck T von and Schmidt A M 1999 The magnetic views on the marine paleoenvironment: Parameters, techniques and potentials of rock magnetic studies as a key to paleoclimatic and paleoceanographic changes; In: Use of Proxies in Paleoceanography: Examples from the South Atlantic (eds) Fischer G and Wefer G (Berlin, Heidelberg: SpringerVerlag) pp 575-599.

Kent D V 1982 Apparent correlation of paleomagnetic intensity and climatic records in deep sea sediments; Nature 299 538-539.

Kirschvink J L, Chang Shih-Bin R 1984 Ultrafine-grained magnetite in deep-sea sediments: Possible bacterial magnetofossil; Geology 12 559-562.

Maiti S, Meena N K, Sangode S J and Chakrapani G J 2005 Magnetic susceptibility studies of soils in Delhi; J. Geol. Soc. India 66 667-672.
Mead G A, Tauxe L and LaBrecque J L 1986 Oligocene paleoceanography of the South Atlantic: paleoclimatic implications of sediment accumulation rates and magnetic susceptibility measurements; Paleoceanography 1 $273-284$

Murray R W and Leinen M 1993 Chemical transport to the seafloor of the equatorial Pacific Ocean across a latitudinal transect at $135^{\circ} \mathrm{W}$ : tracking the sedimentary major, trace and REE element fluxes at the equator and the intertropical convergence zone; Geochim. Cosmochim. Acta. 57 4141-4163.

Murray R W and Leinen M 1996 Scavenged excess aluminum and its relationship to bulk titanium in biogenic sediments from the central equatorial Pacific Ocean; Geochim. Cosmochim. Acta. 60 3869-38378.

Parthiban G 2005 Quaternary sedimentation in the Central Indian Ocean: Response to Himalayan weathering and climatic variation; Ph.D. Thesis. Goa University, Goa, pp 142.

Pattan J N and Shane P 1999 Excess Aluminum in deep sea sediments of the Central Indian Basin; Mar. Geol. 161 247-255.

Pattan J N, Pearce N J G and Mislankar P G 2005 Constraints in using cerium anomaly of bulk sediments as an indicator of paleo bottom water redox environment: a case study from the Central Indian Ocean Basin; Chem. Geol. 221 260-278.

Petrovsky E, Kapiaka A, Zapletal K, Ebstova E, Spanila, Dekkers M J and Rochette P 1998 Correlation between magnetic parameters and chemical composition of lake sediments from northern Bohemia-preliminary study; Phys. Chem. Earth. 23 1123-1126.

Robinson S G 1986 The late Pleistocene paleoclimate record of North Atlantic deep-sea sediments revealed by mineralmagnetic measurements; Phys. Earth Planet. Inter. 42 22-47.

Sager W W and Hall S A 1990 Magnetic properties of black mud turbidities from ODP Leg 116, distal Bengal Fan, Indian Ocean; In: Procds. of the Ocean Drilling Program, Scientific Results (eds) Cochran J R, Stow D A V et al, Ocean Drilling Program, College Station, 317-336 pp.

Sangode S J, Suresh N and Bagati T N 2001 Godavari source in the Bengal fan sediments: results from magnetic susceptibility dispersal pattern; Curr. Sci. $\mathbf{8 0}$ 660-664.

Shankar R, Subbarao K V and Kolla V 1994 Magnetic susceptibility studies of surfacial sediments from the deep Arabian Sea; J. Geol. Soc. India 43 159-167.

Stolz J F, Chang, Shih-Bin R and Kirschvink J L 1986 Magnetotactic bacteria and single-domain magnetite in hemipelagic sediments; Nature 321 849-851.

Thomson R and Oldfield F 1986 Environmental Magnetism; Allen and Unwin, London, pp. 220.

Timothy D A and Calvert S E 1998 Systematics of variations in excess $\mathrm{Al}$ and $\mathrm{Al} / \mathrm{Ti}$ in sediments from the central equatorial Pacific; Paleoceanography 13(2) $127-130$.

Verosub K L and Roberts A P 1995 Environmental magnetism: past, present and feature; J. Geophys. Res. 100 $2175-2192$

Yamazaki T and Ioka N 1997 Environmental rock magnetism of pelagic clays: Implications for Asian eolian input to the North Pacific since the Pliocene; Paleoceanography 12 111-124. 